\title{
Optimization PV/Batteries System: Application in Wouro Kessoum Village Ngaoundere Cameroon
}

\author{
Sadam Alphonse1 ${ }^{*}$, Bikai Jacques ${ }^{1}$, Kitmo²$^{2}$, Repele Djidimbele², Pondi Andre ${ }^{3}$, Kapseu Cesar ${ }^{4}$ \\ ${ }^{1}$ UFD PAI, Laboratory of Analysis of Simulation and Testing, IUT de Ngaoundéré, Ngaoundere, Cameroon \\ ${ }^{2}$ Department of Renewable Energy, National Advanced School of Engineering of University of Maroua, Maroua, Cameroon \\ ${ }^{3}$ Energie and Environmental Technology Analysis Laboratory, Yaounde, Cameroon \\ ${ }^{4}$ The University of Ngaoundere, ENSAI-Ngaoundere, Ngaoundere, Cameroon \\ Email: *ssadamalphonse@yahoo.fr
}

How to cite this paper: Alphonse, S., Jacques, B., Kitmo, Djidimbele, R., Andre, P. and Cesar, K. (2021) Optimization PV/Batteries System: Application in Wouro Kessoum Village Ngaoundere Cameroon. Journal of Power and Energy Engineering, 9, 50-59.

https://doi.org/10.4236/jpee.2021.911003

Received: February 10, 2021

Accepted: November 19, 2021

Published: November 22, 2021

Copyright () 2021 by author(s) and Scientific Research Publishing Inc. This work is licensed under the Creative Commons Attribution International License (CC BY 4.0).

http://creativecommons.org/licenses/by/4.0/

\begin{abstract}
This paper presents the optimization of the PV/battery system including extrapolation of the electrical demand. Matlab software was chosen to implement the algorithm. PVC, the number of PV modules and battery capacity increase with increasing electrical demand. This makes it possible to predict the device according to the electrical demand. Particle swarm optimization is used to minimize the total cost of the system over 20 years. The average cost of energy is $\$ 0.369 / \mathrm{kWh}$.
\end{abstract}

\section{Keywords}

Optimization, Extrapolation, Increasing, Electrical Demand, Particle Swarm Optimization

\section{Introduction}

In Cameroon, $81 \%$ of households in rural areas and $12 \%$ in urban areas still do not have electricity [1]. The average solar radiation in Cameroon is 4.9 $\mathrm{kWh} / \mathrm{m}^{2} /$ day for the whole country. This solar potential is sufficient for the development of energy uses [2]. The government continues to promote the use of the photovoltaic system. In an autonomous installation, photovoltaic energy is compared to the energy demand in a given locality. [3] estimated the daily energy demand in a village which is $1523 \mathrm{KWh}$. Similarly [4], also identified energy demand in a locality in Nigeria. However, they did not include variation in energy demand. To satisfy the demand for energy, an optimization study is needed. [5] optimized the autonomous PV system in a residence by an objec- 
tive function. [6] identified the solar potential in Cameroon. They show that the global solar radiation received in Cameroon varies between 2.9052 $\mathrm{kWh} / \mathrm{m}^{2} /$ day and $4.9709 \mathrm{kWh} / \mathrm{m}^{2} /$ day for Yaounde, $3.1159 \mathrm{kWh} / \mathrm{m}^{2} /$ day and $6.2602 \mathrm{kWh} / \mathrm{m}^{2} /$ day for Garoua, $2.8535 \mathrm{kWh} / \mathrm{m}^{2} /$ day and $5.9245 \mathrm{kWh} / \mathrm{m}^{2} /$ day for Bamenda. The average solar potential in Cameroon is $7.431 \times 10^{8} \mathrm{GWh}$ per year. This potential is exploitable and Cameroon is a country which abounds in solar potential.

\section{Mathematical Model of the PV Module}

There are two main types of photovoltaic model [7]: the electrical model or the equivalent model (with one diode or two diodes). Voltage and current are a function of solar irradiation and temperature. The energy model where the power supplied by the solar module is a function of the efficiency of the solar module, its area, the temperature of the module and solar irradiation

\subsection{The Electrical Model}

A photovoltaic cell behaves simply as an ideal current source which produces a current I proportional to the incident light power, in parallel with a diode which corresponds to the p-n transition area of the cell PV (Figure 1) [7].

According to Pouillet's law:

$$
\begin{gathered}
I_{P h}=I_{D}+I \\
I=I_{P h}-I_{s}\left[\exp \left(\frac{q V}{n K T}\right)-1\right]
\end{gathered}
$$

$I_{s}:$ The reverse saturation current of the diode, $q$ : The charge of the electron $=$ $1.6 \times 10^{-19}(\mathrm{C}), k$. Boltzmann's constant $=1.38 \times 10^{-23}(\mathrm{~J} / \mathrm{K}), T$ : The temperature of the junction.

$I_{d}$. The current flowing in the diode.

This model is theoretical and does not reflect the behavior of a photovoltaic cell in real conditions. It does not take into account the loss of voltage and leakage current. There are other models, admittedly theoretical, but which more accurately reflect the behavior of the photovoltaic cell (Figure 2).

$$
I=I_{p h}-I_{D}-I_{p}
$$

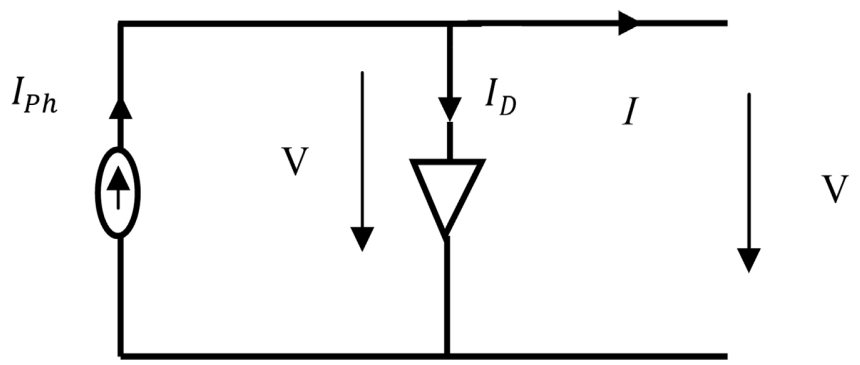

Figure 1. Model of a PV cell. 


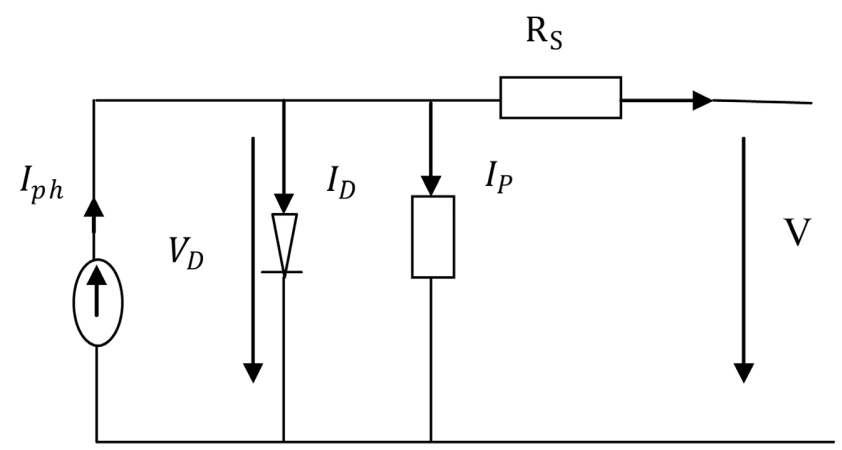

Figure 2. PV cell model taking into account voltage loss and leakage current.

$$
\begin{gathered}
I_{p}=\frac{V_{D}}{R_{P}}=\frac{V+I R_{s}}{R_{P}} \\
I=I_{p h}-I_{s}\left[\exp \left(\frac{q(V+I R)}{a K T}\right)-1\right]-\frac{V+I R_{s}}{R_{P}}
\end{gathered}
$$

This model does not include the radiation effect as there is exchange between the air and the photovoltaic module. Thus (Yahya et al. 2008) [8] held account the radiation effect. The model is described by the following equation:

$$
\begin{gathered}
I=I_{c c}\left[\alpha-\beta\left(\mathrm{e}^{y\left(V-V_{c o}+R_{s} \cdot I\right)}\right)\right]+\lambda\left(T-T_{r e f}\right)-\frac{V+I \cdot R_{s}}{R_{s h}} \\
\beta=1+\frac{R_{s}}{R_{s h}} \\
y=\frac{1}{V_{T}} \\
\alpha=\frac{\psi}{1000}
\end{gathered}
$$

$\lambda$ is a coefficient characterizing variation of power as a function of temperature. $T_{\text {ref }}$ is the temperature of the module under standard conditions, $\Psi$ the luminous flux $\left(\mathrm{W} / \mathrm{m}^{2}\right) . V_{c o}$ the open circuit voltage. The electric model allows knowing the electrical quantities. For a photovoltaic system, the energy model is the most appropriate. Many of the works do not take into account. Also, there are several models which describe the temperature of the solar module noted $T_{c}$. Models that take into account ambient temperature and solar irradiation [9]. And others are differentiated by the nominal operating cell temperature NOCT [10].

$$
P_{p v}(t)=P_{\max } \times\left(\frac{R}{R_{r e f}}\right) \times\left[1+\alpha_{T}\left(T_{c}-T_{a-r e f}\right)\right]
$$

with

$$
T_{c}=T_{a}+\left[\frac{N O C T-20}{800}\right] \times R
$$


$P_{p v}(t)$ is the power generated in time $t$ expressed in (W), $P_{\max }$ is the nominal power of the panel, $R$ and $R_{\text {ref }}$ are the solar and reference irradiation $\left(\mathrm{W} / \mathrm{m}^{2}\right)$. $T_{\text {a-ref }}$ is the temperature under normal conditions. $T_{c}$ is cell temperature $\left({ }^{\circ} \mathrm{C}\right) . T_{a}$ is the ambient temperature $\left({ }^{\circ} \mathrm{C}\right)$. The temperature of the solar module was presented under another model [11] [12].

$$
T_{c}=T_{a}(1+1.25 \xi)
$$

with $\xi$ solar radiation.

The present cost value $(P V C)$ of $\mathrm{PV}$ generator is given in the following relationship [13] [14] [15]:

$$
P V C_{P V}=I_{P V}+c_{o m r, P V}\left(\frac{1+i}{r-i}\right)\left[1-\left(\frac{1+i}{1+r}\right)^{n}\right]-s_{P V}\left(\frac{1+i}{1+r}\right)^{n}
$$

\subsection{Modeling of the Battery}

A $1000 \mathrm{Ah}, 48 \mathrm{~kW} \cdot \mathrm{h}$ Nickel Iron battery (Ni-Fe) bank with 80\% DOD and 1\% self-discharge per day have been used in this work, the usable energy of the battery is $50 \mathrm{~kW} \cdot \mathrm{h}$. An MPPT (Maximum Power Point Tracker) charge control with a maximum of $100 \mathrm{~A}$ outputs has been used with the battery bank with a typical $99 \%$ efficiency. Since the lifetime of the battery bank is 20 years, which is equal to the project lifetime. The available battery bank capacity [16] [17]:

$$
C_{\text {bat }}(t)=C_{\text {bat }}(t-1)(1-\sigma)+(\text { surpluspower }) \eta_{b}
$$

On the other hand, when the available energy generated is less than load demand, the battery bank is in discharging state.

$$
C_{b a t}(t)=C_{b a t}(t-1)(1-\sigma)-(\text { deficitpower })
$$

where $C_{b a t}(t)$ and $C_{b a t}(t-1)$ are the available battery bank capacity (Wh) at hour $t$ and $t-1$, respectively; $\eta_{b}$ is the battery efficiency during discharging process, the battery discharging efficiency was set equal to 1 and during charging, the efficiency is $0.65-0.85$ depending on the charging current [18]. the lifetime of the battery bank is 20 years, which is equal to the project lifetime, its replacement cost is zero. $P V C_{B a t}$ of the battery bank can be calculated as:

$$
P V C_{\text {Bat }}=I_{\text {Bat }}+c_{\text {omr bat }}\left(\frac{1+i}{r-i}\right)\left[1-\left(\frac{1+i}{1+r}\right)^{n}\right]-S_{\text {Bat }}\left(\frac{1+i}{1+r}\right)^{n}
$$

\section{Load Profile (Electrical Demand)}

The electrical demand is that of the work of [19]. Load demand profile (electrical demand) varies with the variation of households in Wouro Kessoum village. The variation of load profile is given by the extrapolation with the following equation [19]:

$$
P_{\text {load }}^{t}=N * P d^{t}
$$

The extrapolation of electrical demand will be is included in the algorithm for optimization. 
Total energy demand over a period of one year $\left(P t_{\text {load }}\right)$ can be expressed as follow

$$
P t_{\text {load }}=\sum_{t=1}^{T} P_{\text {load }}^{t}, \quad T=8760
$$

\section{Problem Formulation}

\section{Objective Functions}

We have tree objectives function:

$$
\begin{gathered}
\text { Object } 1=\min f\left(N_{p v}, N_{W T}, E_{E S S}\right)=N_{p v} \cdot C_{p v}+C_{E S S} \cdot E_{E S S} \\
\text { Object } 2=\min (C O E) \\
\text { Object } 3=\min (T N P C)=\min \left(\frac{P V C, \text { tot }}{C R F}\right) \\
C O E=\frac{P V C, \text { tot }}{E_{\text {served }}}
\end{gathered}
$$

with

$$
\begin{gathered}
E_{\text {served }}=E_{P V}+E_{W T} \\
P V C, \text { tot }=P V C_{P V}+P V C_{W T}+P V C_{B a t} \\
C R F=\frac{i(1+i)^{n}}{(1+i)^{n}-1}
\end{gathered}
$$

\section{Constraints:}

- PV power limits:

$$
P_{p v \min } \leq P_{p v}(t) \leq P_{p v \max } ; \quad N_{P V} \geq 0
$$

- ESS stored energy and power limits:

$$
\begin{aligned}
& E_{E S S \text { min }} \leq E_{E S S}(t) \leq E_{E S S \text { max }} \\
& E_{E S S_{\text {min }}}=(1-D O D) \cdot E_{E S S \text { max }}
\end{aligned}
$$

- Power balance:

$$
P_{p v}(t) \pm P_{E S S}(t) \geq P_{\text {load }}(t)
$$

with $P_{\text {load }}^{t}=N * P d^{t}$.

The system reliability was reliability (the hybrid system satisfied the load by $100 \%)$.

\section{Particle Swarm Optimization}

Particle swarm optimization is an evolutionary algorithm that uses a population of candidate solutions to develop an optimal solution to the problem. This algorithm has been proposed Russel Eberhart and James Kennedy in 1995 [20]. He was originally inspired by the living world, more precisely by behavior of animal living in swarms, flights groups of birds. Indeed, we can observe in these animals movement dynamics relatively complex, whereas individually each individual 
has an "intelligence" limited, and has only local knowledge of her situation in the swarm. Local information and the memory of each individual are used to decide their shifting. Simple rules, such as "stay close to other people", "go in the same direction" or "going at the same speed", are sufficient to maintain cohesion of the swarm, and allow the implementation of complex collective behaviors and adaptive. The particle swarm is a population of simple agents called particles. Each particle is considered as a solution of problem, where it has a position (the solution vector) and a speed. In addition, each particle has a memory allowing him to remember his best performance (in position and in value) and the best performance achieved by the "neighboring" particles (informants): each particle has in fact a group of informants, historically called its neighborhood. Each individual in PSO represents a possible solution assumed to have two properties: velocity and position. Each particle wanders through in the solution area and recalls the best objective function value (position), which has already been discovered; the fitness value is saved and known Pbest. When a particle captures all the best population as its topological neighbors, the superior value is a global best and it is called Gbest. The particles flight with a certain velocity in the D-dimensional space to find the optimal solution. Let the variable $\left(x_{i}\right)$ refers to the position of particle $(i)$ in the study space and its speed is $\left(V_{i}\right)$, so the $\left(i_{\text {th }}\right)$ from the particle can be represented as ( $\mathrm{Lu}$ et al., 2015):

$$
x_{i}=\left[x_{i 1}, x_{i 2}, x_{i 3}, \cdots, x_{i D}\right]
$$

The best past position of the th particle is saved under the name vector and calculated by:

$$
P_{i}=\left(p_{i 1}, p_{i 2}, \cdots, p_{i D}\right)
$$

where $i=1,2,3, \cdots, N$ is the number of particles in a swarm,

$$
v_{i}(t+1)=w(t) v_{i}(t)+c_{1} r_{1}\left(P_{i}(t)-X_{i}(t)\right)+c_{2} r_{2}(G(t)-X(t))
$$

The $r_{1}$ and $r_{2}$ are random real numbers drawn from $[0,1], c_{1}$ and $c_{2}$ are acceleration constants that pull each particle towards. The procedure for the implemented PSO is as the following Set PSO parameters: population size $\left(N_{P_{o p}}\right)=$ $200,\left(c_{1}\right)=1.8,\left(c_{2}\right)=2, \chi=0.7$, total number of iteration $=100$, the Set dimension of the search variables: the lower and upper bound respectively: lower and upper bound of number of PV systems $(0,50)$. Lower and upper bound of number of battery banks $(0,100)$.

\section{Results and Discussion}

Study focuses on the economic optimisation. Three objective functions are defined. Objective function base on minimization of the cost of energy production (COE), total net present cost (TNPC) and number of PV module and batteries $\left(N_{P V}, N_{B}\right)$ taking account some constraints like the rising of the electrical demand, PV power limits, and batteries power limits. The PSO algorithm was developed by Matlab. The data of solar energy, wind energy temperature and air 
density was inserted. The location of Wouro Kessoum (Ngaoundere), Cameroon (Latitude $7^{\circ} 20^{\prime} \mathrm{N}$, Longitude $13^{\circ} 34^{\prime} \mathrm{E}$, Altitude $1120 \mathrm{~m}$ ) is used as site for the case study. The global horizontal solar irradiance (Figure 3) is minimal in November, December, January and February. Ambient temperature (Figure 4) is minimal in June, July and August. The data were taken from the reception center of the Vantage Pro2 station of the IUT of Ngaoundere and used to calculate the Output powers of the PV and WT. The characteristic of PV modules and batteries are presented in Table 1. Optimal combination system is presented in Table 2. In this table, the TNPC increase with the increase in the number of household. For $n$ $=50$, the TNPC is $\$ 275,253.02$. With the increase of the population in village, the algorithm allows predicting the TNPC and the components ( $\left.N_{P V}, N_{W T}, E_{E S S}\right)$.

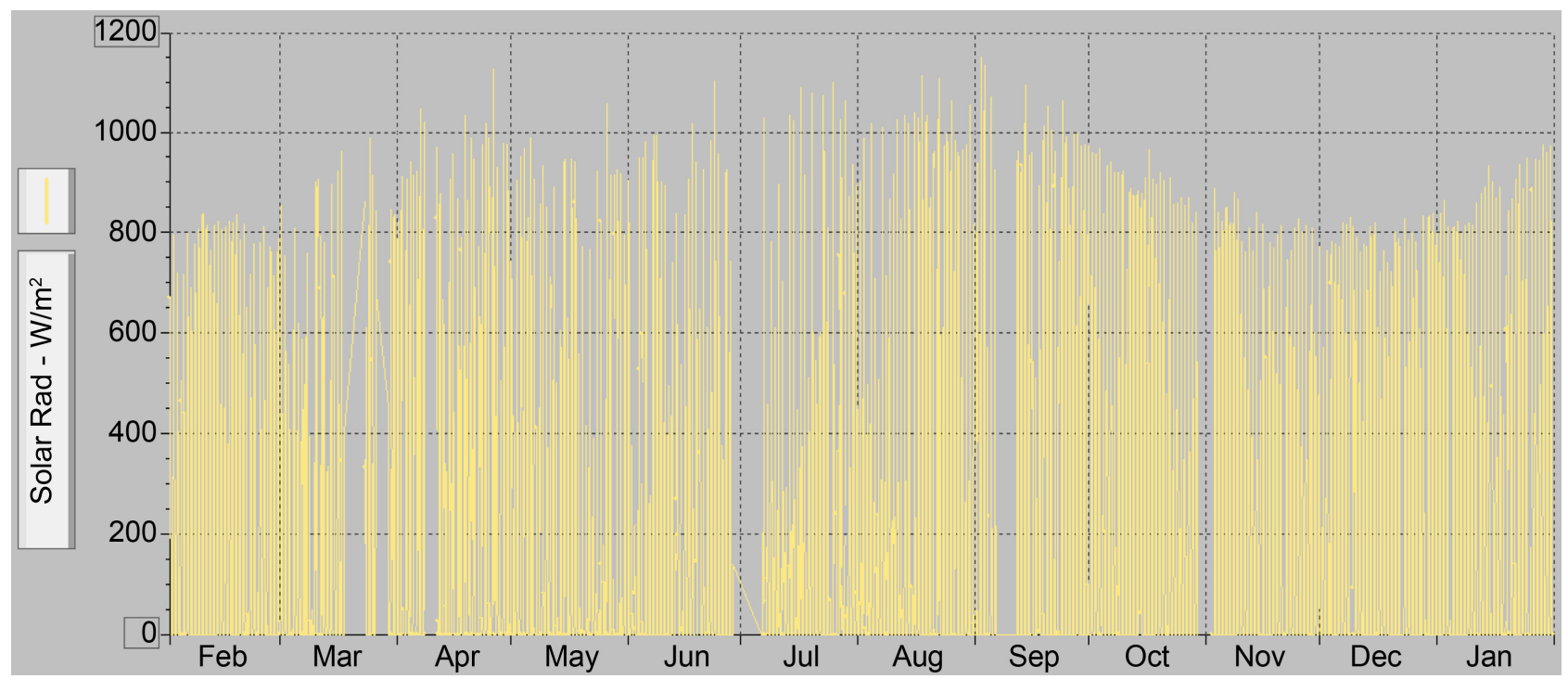

Figure 3. Monthly global solar irradiation of the year $\left(\mathrm{W} / \mathrm{m}^{2}\right)$.

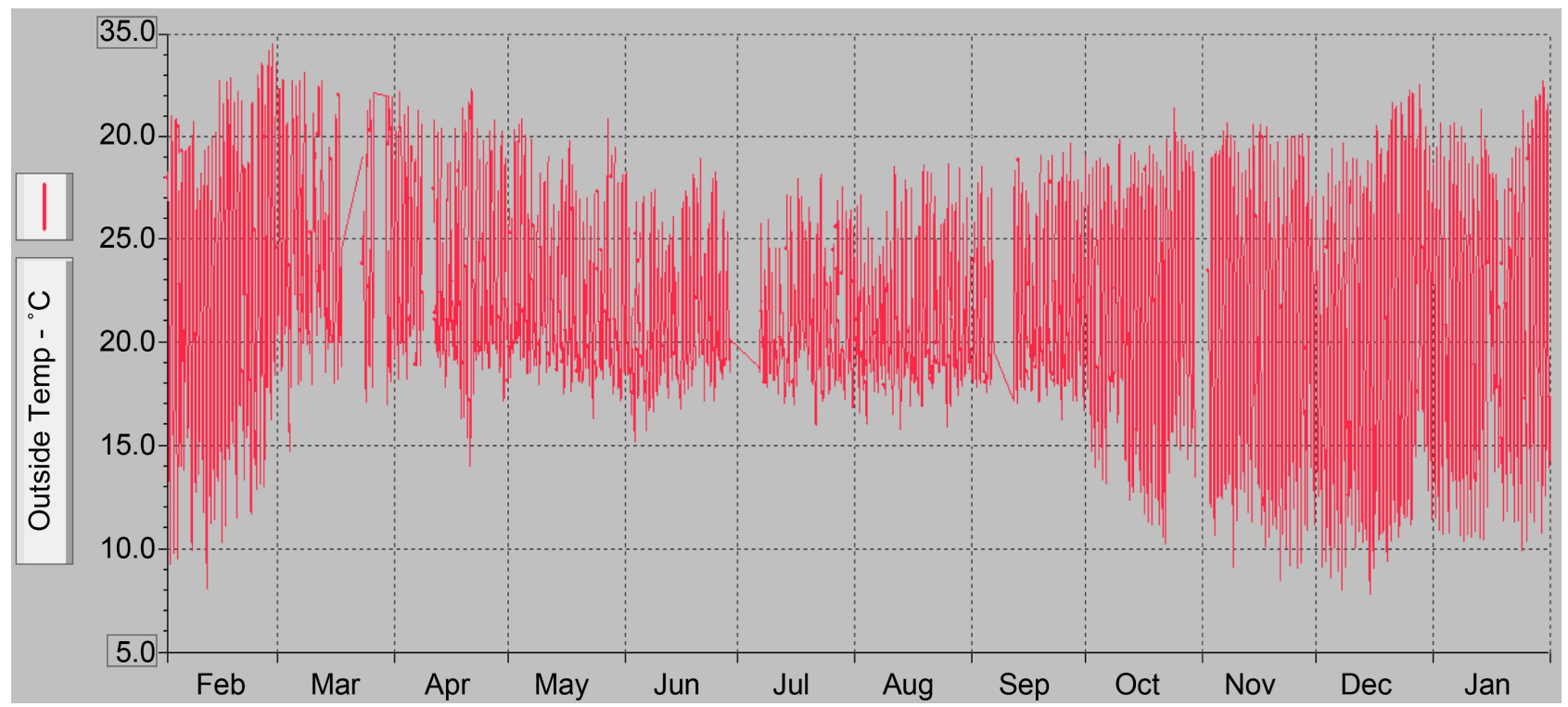

Figure 4. Monthly ambient temperature of the year $\left({ }^{\circ} \mathrm{C}\right)$. 
For $n=100 ; 150 ; 195$, the TNPC are $\$ 321,141.10 ; \$ 460,725.20 ; \$ 490,920.17$. Figure 5 shows the variation of the Cost of Energy (COE) for a year. The minimal cost of the energy is in July and August (\$0.346) and the maximal cost of the energy is in November and December (\$0.433). Diminution of energy increases the cost of energy (Equation (22)). The average cost energy per kWh for a year is $\$ 0.369 / \mathrm{kWh}$. This is the price that the population of this village can pay as the price per kilowatt hour.

Table 1. Components characteristics and their corresponding costs.

\begin{tabular}{cccc}
\hline \multicolumn{1}{c}{ Photovoltaic } & & \multicolumn{2}{c}{ Batteries bank } \\
\hline Parameters & Values & Parameters & values \\
\hline The rated power & $255 \mathrm{~W}$ & Price & $71 \%$ \\
efficiency $\eta$ & $90 \%$ & Efficiency $\eta$ & \\
The lifetime & 20 & Rated energy & $50 \mathrm{~kW} \cdot \mathrm{h}$ \\
Price/PV $(30 \mathrm{~kW})$ & $\$(42,000)$ & Nominal voltage & $100 \mathrm{v}$ \\
\hline
\end{tabular}

Table 2. Optimal combination system.

\begin{tabular}{cccccc}
\hline & $n=50$ & $n=100$ & $n=150$ & $n=195$ & $n=250$ \\
\hline Number of PV module & 48 & 55 & 79 & 84 & 85 \\
Number of battery (kWh) & 210 & 461 & 512 & 632 & 639 \\
TNPC (\$) & $275,253.02$ & $321,141.10$ & $460,725.20$ & $490,920.17$ & $531,764.11$ \\
\hline
\end{tabular}

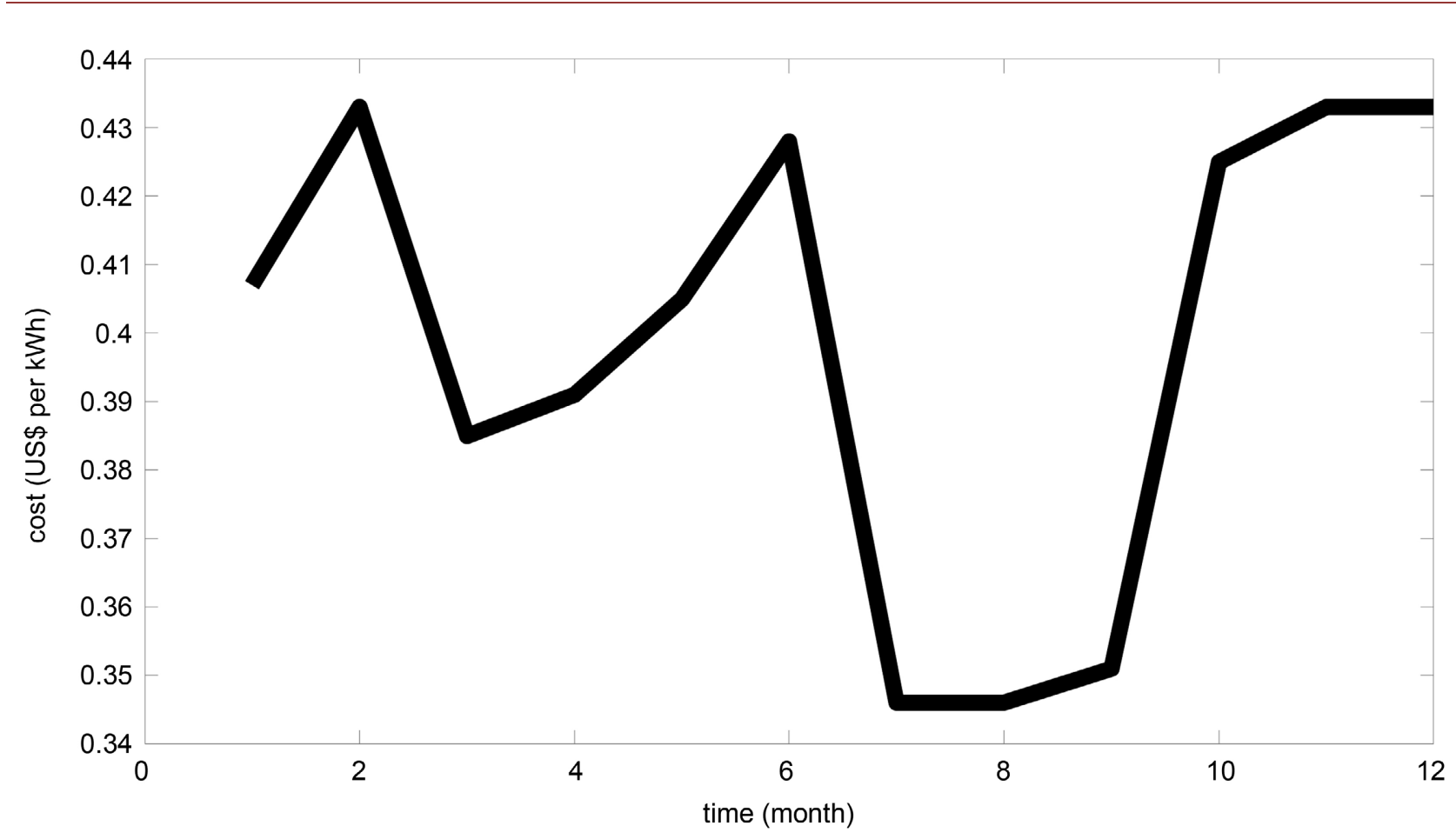

Figure 5. Cost of energy (US\$per kWh). 


\section{Conclusion}

This work highlights the optimum costs, the number of PV modules and the size of the batteries. To do this, the characteristics of the elements were evaluated. The particle swarm method has been chosen to optimize. The optimization constraints have been determined. The constantly increasing demand for energy in a locality is an important factor. Why this factor was taken as constraint. The cost of energy in this locality is $\$ 0.369 / \mathrm{kWh}$.

\section{Conflicts of Interest}

The authors declare no conflicts of interest regarding the publication of this paper.

\section{References}

[1] Tatsinkou, C. (2016) Seminar on Mainstreaming Energy Sustainable Development Goals (SDGs), Targets and Indicators into Statistical Programmes. United Nations.

[2] Kouam, A. and Tchuen, G. (2015) Optimisation d'un système hybride de production d'énergie. Revue des Energies Renouvelables, 18, 529-538.

[3] Sèmassou, G., Nadeau, J.P., Sebastian, P., Pailhès, J. and Vianou, A. (2013) Optimisation multicritère en conception de système photovoltaïque pour des maisons individuelles en contexte africain. Revue des Energies Renouvelables, 16, 225-247.

[4] Traoré, A., Elgothamy, H. and Zohdy, M. (2018) Optimal Sizing of Solar/Wind Hybrid Off-Grid Microgrids Using an Enhanced Genetic Algorithm. Journal of Power and Energy Engineering, 6, 64-77. https://doi.org/10.4236/jpee.2018.65004

[5] Okoye, C.O. and Oranekwu-Okoye, B.C. (2018) Economic Feasibility of Solar PV System for Rural Electrification in Sub-Sahara Africa. Renewable and Sustainable Energy Reviews, 82, 2537-2547. https://doi.org/10.1016/j.rser.2017.09.054

[6] Mboumboue, E. and Njomo, D. (2016) Potential Contribution of Renewables to the Improvement of Living Conditions of Poor Rural Households in Developing Countries: Cameroon's Case Study. Renewable and Sustainable Energy Reviews, 61, 266-279. https://doi.org/10.1016/j.rser.2016.04.003

[7] Singo, A. (2010) Système d'alimentation photovoltaïque avec stockage hybride pour l'habitat énergétiquement autonome. Ph.D. Thesis, Université Henri Poincaré, Nancy.

[8] Yahya, A., Mahmoud, A. and Youm, I. (2008) Etude et modélisation d'un générateur photovoltaïque. Revue des Energies Renouvelables, 11, 473-483.

[9] Lalwani, M., Kothari, D.P. and Singh, M. (2011) Size Optimization of Stand-Alone Photovoltaic System under Local Weather Conditions in India. International Journal of Applied Engineering Research, 1, 951-961.

[10] Khenfous, S., Kaabeche, A., Bakelli, Y. and Sba, K. (2018) Optimal Size of Renewable Hybrid System Applying Nature-Inspired Algorithms. 2018 International Conference on Wind Energy and Applications in Algeria (ICWEAA), Algiers, 6-7 November 2018, 1-6. https://doi.org/10.1109/ICWEAA.2018.8605047

[11] Messenger, R.A. and Ventre, J. (2003) Photovoltaic Systems Engineering. 2nd Edition, CRC Press, Boca Raton.

[12] Shen, W.X. (2009) Optimally Sizing of Solar Array and Battery in a Standalone Photovoltaic System in Malaysia. Renewable Energy, 34, 348-352.

https://doi.org/10.1016/j.renene.2008.03.015 
[13] Li, M. and Li, X. (2005) MEP-Type Distribution Function: A Better Alternative to Weibull Function for Wind Speed Distributions. Renewable Energy, 30, 1221-1240. https://doi.org/10.1016/j.renene.2004.10.003

[14] Sarkar, M. and Hussain, M. (1991) The Potential of Wind Electricity Generation in Bangladesh. Renewable Energy, 1, 855-857.

https://doi.org/10.1016/0960-1481(91)90038-Q

[15] Dahmouni, A.W., Ben Salah, M., Askri, F., Kerkeni, C. and Ben Nasrallah, S. (2011) Assessment of Wind Energy Potential and Optimal Electricity Generation in Borj-Cedria, Tunisia. Renewable and Sustainable Energy Reviews, 15, 815-820. https://doi.org/10.1016/j.rser.2010.07.020

[16] Diaf, S., Diaf, D., Belhamel, M., Haddadi, M. and Louche, A. (2007) A Methodology for Optimal Sizing of Autonomous Hybrid PV/Wind System. Energy Policy, 35, 5708-5718. https://doi.org/10.1016/j.enpol.2007.06.020

[17] Barakat, S., Ibrahim, H. and Elbaset, A.A. (2020) Multi-Objective Optimization of Grid-Connected PV-Wind Hybrid System Considering Reliability, Cost, and Environmental Aspects. Sustainable Cities and Society, 60, Article No. 102178. https://doi.org/10.1016/j.scs.2020.102178

[18] Ai, B., Yang, H., Shen, H. and Liao, X. (2003) Computer-Aided Design of PV/Wind Hybrid System. Renewable Energy, 28, 1491-1512. https://doi.org/10.1016/S0960-1481(03)00011-9

[19] Alphonse, S., Bikai, J., Fokone, A.T. and Cesar, K. (2020) Potentiel énergétique éolien et profil de consommation d'énergie dans le village Wouro Kessoum Ngaoundéré Cameroun. Revue des Energies Renouvelables, 23, 72-85.

[20] Kennedy, J. and Eberhart, R. (1995) Particle Swarm Optimization. Proceedings of ICNN95-International Conference on Neural Networks, Perth, 27 November-1 December 1995, 1942-1948. https://doi.org/10.1109/ICNN.1995.488968

\section{Nomenclature}

\begin{tabular}{ll}
\hline COE, Cost of energy & CRF, Capital recovery factor \\
PVC, Present cost value & $i$, inflation rate \\
TNPC, Total net present cost & $r$, interest rate \\
PV, Photovoltaic & $P_{\text {load, }}$ total electrical demand \\
$n$, useful lifetime & $N$, number of household \\
$\eta$, efficiency & $P d$, electrical demand for one household \\
\hline
\end{tabular}

